\title{
Emptiness and the Eight Consciousnesses: Toward a Deeper Understanding of Intuitive Judgment
}

\author{
Jen-Sheng Liao ${ }^{1}$, Charles S. Chien ${ }^{2}$ \\ ${ }^{1}$ College of Business, Feng-Chia University, Taichung City, Taiwan \\ Correspondence: Jen-Sheng Liao, College of Business, Feng-Chia University, Taichung City, 40724, Taiwan. Tel: \\ 886-4-2526-2165. E-mail: jenshengliao@yahoo.com.tw
}

Received: October 24, 2017

doi:10.5539/ass.v14n1p11

\author{
Accepted: November 6, $2017 \quad$ Online Published: December 27, 2017 \\ URL: https://doi.org/10.5539/ass.v14n1p11
}

\begin{abstract}
This paper empirically investigates whether emptiness (according to the Mādhyamaka school) has a positive association with the intuitive judgment that results from the eight consciousnesses (according to the Vijñānavāda school). A questionnaire-based quantitative approach was used to collect data from 157 professional spirit mediums. The results show that emptiness is significantly correlated with pure brightness and that pure brightness is, in turn, is significantly associated with intuitive judgment. Therefore, this paper argues that emptiness can improve or enhance the eight consciousnesses in making moral decisions. Finally, for the gap between moral judgment and action, this research provides new insight by asserting that this gap must have existed a priori.
\end{abstract}

Keywords: emptiness, eight consciousnesses, intuition, intuitive judgment

\section{Introduction}

\subsection{Background}

The Mahāyāna stream of Chinese Buddhism often distinguishes between the Mādhyamaka and Vijñānavāda, taking the former as exclusively acknowledging all phenomena of emptiness (śünyatāa)(Kaag, 2012) and the latter as concentrated single-mindedly on the ideation (vijñaptimātra) of the universe (Nedu, 2015). The concepts of the main subjects of the investigations of these schools are assumed to be in conflict (Duckworth, 2014), since the idea of emptiness is not at all present in the teachings of the Vijñānavādaschool and idealism is absent from those of the Mādhyamaka (King, 1994). Although they are distinct, these two discourses are also closely intertwined, for Vijñānavāda practitioners only analyze and describe how human experience is constructed by the mind to serve, pragmatically, the abstruse aims of the Mādhyamaka: the Prajñāpāramitā state that people undergo in attaining emptiness and freedom from cognitive obscurations and emotional obsessions(Waldron, 2006).However, one must also recognize that there was an essential development in the hermeneutics of the doctrine of emptiness in Vijñānavāda (King, 1994). This event surfaced critical issues in the effect of emptiness in Vijñānavāda. However, until recently, empirical research on the role of emptiness in Vijñānavāda was almost non-existent.

According to the Vijñānavāda school, conceptual knowledge appears at the level of mental consciousness (the sixth consciousness), which, in its turn, is determined by manas consciousness (the seventh consciousness). Because manas consciousness is responsible for the misconception of the individual self, this error will also characterize any form of conceptual knowledge that appears at the level of mental consciousness. Thus, the theory of the conditioning of decision-making states that this conditioning is affected by two factors: manas consciousness of individuality and the seeds of âlayavijnâna (the eighth consciousness) (Nedu, 2015).

\subsection{Objectives}

This paper empirically investigates whether emptiness has a positive association with the intuition that results from the eight consciousnesses (viz. Vijñānavāda). This analysis can provide much edification for inducing morally intuitive decisions. This task is especially challenging, because of the unfamiliarity of most readers of English with Buddhist philosophy. The research result may shift modes of thought and lead to profound differences in how we make decisions from intuition. This paper will address the concept of Vijñānavāda before describing the empirical experiments. 


\section{Literature Review}

\subsection{Emptiness (Śünyatā; Sanskrit)}

Mādhyamaka and Yogācāra (called Vijñānavāda in China) represent two schools of Mahāyāna Buddhism. During the seventh century, after the famous pilgrim Tripitaka Master Xuanzang (玄藏, AD 602-664) introduced a new corpus of canonical Buddhist texts, Mādhyamaka and Yogācāra were considered doctrinally contradictory to each other in the polemic circumstance of Emptiness-Existence (i.e., kongyou 空有) and the Buddha nature (Lee, 2016). A comprehensive explication of the notion of emptiness, as found in the philosophical literature of the Mādhyamaka school, provides a doctrinal key to unlock the deep meanings of the Prajñāpāramitā sutras(King, 1994). In the Heart Sutra (心經), the phrase of Prajna-paramita implies that five aggregates of being are all empty (照見五蓝皆空), and emptiness here signifies that noting has an independent, “Ego-nature" or "Ego-appearance" of its own (Cheng Kuan, 2015). Although Yogācārins maintained that there was something given in experience, namely, a non-objective perception, Yogācāra accepts śūnyatā (i.e., emptiness)(King, 1994). Thus, it is difficult to ignore the centrality of the notion of śünyatā to Vijñānavāda.

Śünyatā can indicate the empty, emptiness, empty space, sky, among other meanings. If śünyatā is used in a cosmological sense (as empty space), it is not congruent with the ontological concept of emptiness (śūnyatā, lack of inherent existence) as employed in Mahāyāna philosophy or Daoist mystery (Eskildsen, 2015). Süunyatā is a specialized term in Buddhism. Precisely, it signifies that nothing has an independent ego-nature or ego-appearance of its own, because everything is constituted from various amalgamated parts, and these elements are interdependent and inter-related, forming an "apparent whole," which does not remain intact for even a short duration and is subject to the law of inconstancy. Everything changes from instant to instant, and, therefore, its ultimate ego-nature is ungraspable and unobtainable. Because the ego-appearances of things are unobtainable, it is said that the ego-nature of all beings is empty (Venerable, 2005). In other words, substances and phenomena have no fixed, unchangeable, eternal existence or "self" (Chan, 2015).

When the mind is thoroughly emptied and made calm, it merely observes things as they are without imposing its own biases and wishes. Perhaps when one observes stuff around one and calmly for what they are, one realizes that it is essential to the nature of all things to flourish and decline (Eskildsen, 2015). This situation is called pure brightness.

Pure brightness is expressed by the great concern for the spirit mediums' purity of mind. So as not to interfere with the flow of the god's thoughts, medium's mind has to be calm, clear and obvious of its self (Clart, 2003).

\subsection{Eight Consciousnesses}

The basic concept of Vijñānavāda is that everything is created from the mind as ideation (vijñaptimātra). Vijñānavāda uses the eight consciousnesses to explain the workings of the mind and the way it constructs the reality we experience (Clark, 2011). The doctrine of Verses Delineating the Eight Consciousnesses is used to explain each level of consciousness in this paper. Verses Delineating the Eight Consciousnesses (八識規矩頌), by Tripitaka Master Xuanzang (玄藏, AD 602-664), is a summary of the doctrine contained in Xuanzang's most celebrated work, Treatise on Consciousness Alone (成唯識論).

\subsubsection{Sixth consciousness (mental consciousness).}

The first five consciousnesses are the physical senses (those instantiated in the eye, ear, nose, tongue, and body), and the sixth consciousness is mental consciousness (Clark, 2011). These five senses, accompanied by their objects, are posited by valid, straightforward cognition, solely using bodily sense faculties (Berzin, 2013). Mental consciousness distinguishes all incoming data. Since the first five consciousnesses always arise together with mental consciousness, it and all the sense data are fed into the seventh consciousness (manas)(Clark, 2008). The character or nature of these six consciousnesses can be good, evil, or neutral (Tripitaka Master Xuanzang, 1998). On mental consciousness, it is stated in the Verses, "Whenever it is wholesome or unwholesome, they make distinctions and accompany it. The basic and subsidiary afflictions together with faith and other wholesome dharmas always arise jointly with the sixth consciousness."The primary function of mental consciousness is to make distinctions, such as between good and evil or between long and short. According to Vasubandhu, the fundamental afflictions are greed, anger, stupidity, arrogance, doubt, and improper views. Because these primary afflictions always come together, mental consciousness colors the incoming sense data and interprets it through the senses (Clark, 2011).

\subsubsection{Seventh consciousness (manas consciousness).}

The first six consciousnesses are separated and involve the quick registration of sense impressions. Manas coordinates thoughts and sensory information received from the first six consciousnesses and is capable of 
reflecting, considering, and making judgments (Clark, 2011). In other words, conceptual knowledge appears at the level of mental consciousness, which is determined by manas consciousness (Nedu, 2015). The nature of manas is neutral but obscuring; therefore, mana will be innately contaminated by defiling afflictions (Tripitaka Master Xuanzang, 1998).

The Verses state, "The eight derivative afflictions, the five universal interactions, the judgment of the particular states, greed, anger, doubt, and improper views all interact and accord with it... It continuously focuses its mental activity on inquiry which results in the characteristic that is self."The eight derivative afflictions are "lack of faith, laziness, laxness, torpor, restlessness, distraction, improper knowledge, and scatteredness." Greed, anger, doubt, and improper views are four of the six primary afflictions. These eight derivative afflictions and four fundamental afflictions always interact with manas. Its primary function is to make judgments, which involves decision making based wholly on worldly knowledge, which is defiled by the self (Tripitaka Master Xuanzang, 1998). At the level of manas, the delusion of $I$ arises, because this reflects the illusion that there is someone inside who is in charge, making decisions, acting on my preferences, and consciously pursuing my choices(Clark, 2008).

\subsubsection{Eighth consciousness (âlayavijnâna).}

The eighth consciousness, whose nature is a non-obscuring neutral, always arises together with the seventh consciousness(Tripitaka Master Xuanzang, 1998). Alayavijnâna means the storehouse or seed consciousness, which induces transmigration or rebirth, causing the origination of a new existence (Clark, 2008). Alayavijnâna receives impressions from all the functions of the other consciousnesses and accumulates potential energy for the mental and physical manifestation of life (Berzin, 2013). According to the traditional interpretation, the other seven consciousnesses are evolving or transforming consciousnesses, originating in this seed consciousness. Alayavijnana is a complexly conditioned mode of cognitive awareness that simultaneously supports and informs all occurrences of manifest consciousness (Siderits, 2005). Although it is initially immaculate in itself, âlayavijnâna contains a mysterious mixture of purity and defilement, good and evil. Because of this mix, the transformation of consciousness from defilement to purity can take place(Waldron, 2008).

\subsubsection{Ninth consciousness (amalavijñāna).}

Amalavijñana is the immaculate consciousness. This pure consciousness is identified with the nature of reality. Alternatively, amalavijñanna may be considered the real aspect of alayavijnâna (Buswell\& Lopez, 2013).The concept of amalavijñana ultimately derives from Tathagatagarbha thought, which similarly emphasizes the inherent purity of mind (Buswell, 1989). The intrinsic Buddha nature is called the Tathagatagarbha. According to the Sutra of Queen Srimala of the Lion's Roar (勝蔓經), Tathagatagarbha is eternal, unchanging, and inherently pure. If there were no Tathagatagarbha, there would be no aspiration to seek nirvana. Tathagatagarbha signifies that everyone can be Buddha. The discovery of amalavijñana clears away defilements and wrong views to find the emptiness that is the source of Tathagatagarbha (Clark, 2008).

\subsection{Hypothesis}

\subsubsection{Three Types of Intuition}

Freud divided the mind into the conscious mind and the unconscious mind. Jung then split the unconscious into two layers: the personal unconscious and the collective unconscious. In introducing Buddhist concepts to Western audiences, Waldron (2006) found it useful to consider the conception of the alayavijnâna as a form of Jung's collective unconscious, according to which the world is constructed through a shared language (Siderits, 2005). This paper borrows Jung's concept of intuition to express manas, âlayavijnâna, and amalavijñanna.

- Personal experience intuition (manas consciousness). The personal unconscious consists of complexes and individuals' experience (Jung, 1981). A compound is a core pattern of emotion, memories, perceptions, and wishes (Shultz \& Shultz, 2009). The personal unconscious has a similar function to manas-vijñanna (Pine, 2013). Intuition from manas consciousness is labeled own experience intuition. Because of affliction and self-delusion, this intuition cannot make proper moral judgments.

- Collective archetype intuition (âlayavijinâna).The archetype is one element of the collective unconscious. Archetypes are unclear underlying forms from which emerge images and motifs. History, culture and personal context shape these manifest representations (Jung, 1981). Intuition from alayavijinâna can be called an intuition of the collective archetype. Because of karma, this intuition cannot make proper moral judgments.

- Collective universal intuition (amalavijñāna).Another component of the collective unconscious is the universal image (Raff, 2000). The universal image is an essential thing: the most far-fetched mythological motif and symbol (Jung, 1981). Intuition from here is labeled collective universal intuition. Immaculate and 
pure collective universal intuition is similar to Tathagatagarbha, which represents the core concept of amalavijñāna.

\subsubsection{Hypotheses}

Based on the relevant literature, the results of the studies presented above, and essential variables identified by previous research on ethics, the following hypotheses are proposed concerning the association between emptiness and intuitive judgment.

H1. Emptiness is positively associated with pure brightness.

H2. Pure brightness is positively associated with personal experience intuition.

H3.Pure brightness is positively associated with collective archetype intuition.

H4: Pure brightness is positively associated with collective universal intuition.

\section{Methods}

\subsection{Samples}

Unlike other studies that have taken students or managers as samples, this study examined particular spirit mediums. This was done for the following reason. First, mediumship indicates the ability to communicate with the souls of the dead in spiritualist sessions. The function of intuition in the intermediary state unites mediums and intermediary beings (Pilard, 2015). Since the spirit medium's experience helps others understand unconscious and conscious psychology, spirit mediums are an essential subject for the new psychology (Shamdasani, 2009). Second, according to Fontein (2006), the performances of spirit mediums can involve "responding to, and engaging with, the social, political, and moral expectations of those around them." Also, spirit mediums may have a more profound enlightenment of emptiness than most. The performance of Taiwanese spirit mediums derives from beliefs and practices from Daoism, Buddhism, and Confucianism (Marshall, 2003). They offer a direct conversation with the gods and offer practical or personal advice (Cline, 2010). More studies of Taiwan spirit mediums can be found in Sutton (1989, 1990, 2003), Paper (1995, 1996), Clart (1996, 2003), Nickerson (2001), and Marshall (2004).

\subsection{Setting}

Members of the Taiwan Mediums' Association, founded in 1989, were contacted and invited to participate in the survey. The help of the association allowed the researchers to reach a population that is widely dispersed geographically and difficult to achieve through the conventional survey method; 200 questionnaires were sent to 200 spirit mediums, each living in a different area in Taiwan. In all, 157 responded with completed questionnaires that could be used in the analyses, and 43 responses did not include answers to all items well, and thus we did not use these 43 reactions in our study. This response rate was $78.5 \%$ (157 out of 200). Because Loehl in (2004) has the requirement that the least number of samples should be over 100, our 157 responses match the minimum requirement for structural equation modeling (SEM).

\subsection{Design and measures}

This survey-based approach used one questionnaire to assess emptiness, pure brightness, and three types of intuition (see appendix). The questionnaire items were responded to on a five-point Likert-type scale: agree strongly (5), agree (4), not certain (3), disagree (2), and disagree strongly (1). The definition of each variable is as follows:

- Pure brightness. Pure brightness means that the mind is clear or free of any thoughts that would confuse the mind during decision-making. It also means that the mind is calm, without any emotions to agitate it (Eskildsen, 2015). This was measured using six items (see appendix).

- Emptiness. Śünyatā means emptiness or vacuity, a highly specialized term in Buddhism. Specifically, it signifies that nothing has an independent ego-nature or ego-appearance of its own. It was measured using five items (see appendix).

- Personal experience intuition, collective archetype intuition, and collective universal intuition. These three types of intuition were measured using four items in PEI and three items in CAI and CUI (appendix). The reason we adopted the term clairvoyance in the collective universal intuition is that it resembles the highest faculty that has access to some ultimate reality (Pilard, 2015).

\subsection{Procedure}

Similar to the samples used by Giacalone and Jurkiewicz (2003) and Ayoun, Rowe, and Yassine (2015), the 
snowball sampling technique, often used for hidden populations that are difficult for researchers to access, was employed. To ensure that a good sample would be obtained, the initial distribution of the surveys specifically targeted the Mediums' Association, with the request that recipients pass it on to others who might be interested. Any survey forwarded to expand the sample had a good chance of reaching valid respondents, as the target population was sufficiently diversified (spread throughout Taiwan) to accommodate minor variations in dissemination. Furthermore, as an extra precaution, one question in the survey requested the respondent's job title, to ensure that he or she was a spirit medium in a top position. Another benefit of snowball sampling in this study was that it might have encouraged participation. A survey that measures sensitive subjects, such as spirituality and ethics, may be received better from a friend or familiar colleague than an outsider.

\subsection{Ethical Considerations}

Items in the questionnaire were created by previous studies (see appendix). Before implementing the survey, the questionnaire was approved by the Chairman of the Taiwan Mediums' Association (Mr. Gao, Tian-Wen). The participants in this questionnaire are anonymous. Because the survey was anonymous and participants were not identified by name, this project presented no foreseeable risk to participants. Participants were told that their participation is voluntary and that they can decline to answer specific questions or to end their involvement at any time without penalty. The participants were aware of that the results of this study could be published in professional and social journals. Participants were also informed that the results could also be used for educational purposes or presentation. However, no individual subject will be identified. The questionnaire was approved by the College of Business in Feng-Chia University (NO.20111018P9945756).

\subsection{Analysis}

The data were analyzed with the SPSS package, using reliability, correlation, and regression. Also, SEM and the Rival Model were also used to test validity and model fit (Hancock, 2015).The use of SEM is commonly justified in the social sciences because of its ability to impute relationships between unobserved constructs (latent variables) from observable variables (Loehlin, 2004). Table 1 shows the ideal value of the model fit index in SEM. Also, once the researcher is confident that a plausible hypothesis supports the inferred relationship, he must then rule out the plausibility of rival hypotheses (Campbell \& Stanley, 1963) and models. If the model survives to this point, it may be reasonable to conclude, probabilistically, that a causal relationship has been demonstrated (McCoach et al., 2007).

Table 1. Idea value of model fit index (Bollen \& Long, 1992)

\begin{tabular}{ccc}
\hline$\chi^{2}$ & & Smaller is better \\
\hline$\chi^{2} / \mathrm{df}$ & & $1-5$ \\
GFI & Goodness-of-fit index & $>0.8$ \\
AGFI & Adjusted goodness-of-fit index & $>0.8$ \\
PNFI & Parsimony-adjusted normed fit index & $>0.5$ \\
CFI & Comparative fit index & $>0.9$ \\
RMR & Root mean square residual & $<0.08$ \\
RMSEA & Root mean square error of approximation & $<0.08$ \\
\hline
\end{tabular}

\section{Results}

\subsection{Reliability and Validity}

\subsubsection{Reliability}

All the measures were analyzed for reliability and validity. The appendix contains measured characteristics and sample measurement items. Nunnally (1978) stated that Cronbach's $\alpha$ denotes high reliability if it is between 0.7 and 0.98. If Cronbach's $\alpha$ is above 0.5, the research findings should be regarded as significant. If Cronbach's is under 0.35, the research should be rejected (Hair, Anderson, Tatham, \& Black, 1992). Cronbach's $\alpha$ was 0.682 for emptiness, 0.740 for pure brightness, 0.801 for personal experience intuition, 0.519 for collective archetype intuition, and 0.686 for collective universal intuition. Cronbach's $\alpha$ for the total 21 items was 0.857 . All were over the 0.5 standard value. Therefore, the results of this survey should be considered reliable.

\subsubsection{Validity}

\section{- Content Reliability:}

This paper adopts the relevant references as the research basis, cooperating with an expert spirit medium to discuss, make, pre-test, and re-correct the questionnaire. Therefore, this study should reach content validity. 


\section{- Composite Reliability:}

Confirmatory factor analysis was used to test validity. The composite reliability values of emptiness, pure brightness, personal experience intuition, collective archetype intuition, and collective universal intuition were $0.727,0.744,0.805,0.534$, and 0.824 , respectively. All were more than 0.5 , which showed that they had good construct validity (Raines-Eudy, 2000).

\subsection{Correlation}

The variables for emptiness, pure brightness, personal experience intuition, collective archetype intuition, and collective universal intuition were analyzed using a correlation analysis. Demographic variables for age, years of experience and number of students were also included. Correlation analysis (Table 2) indicated that emptiness had strong correlations with pure brightness $(0.571, \mathrm{p}<0.01)$. Pure brightness had significant correlations with personal experience, collective archetype intuition, and collective universal intuition $(0.181, p<0.05 ; 0.345$, $\mathrm{p}<0.01 ; 0.476, \mathrm{p}<0.01$, respectively). These results provide support for $\mathrm{H} 1, \mathrm{H} 2, \mathrm{H} 3$, and $\mathrm{H} 4$.

Table 2. Correlations

\begin{tabular}{cccccc}
\hline & Emptiness & $\begin{array}{c}\text { Pure } \\
\text { brightness }\end{array}$ & $\begin{array}{c}\text { Personal Experience } \\
\text { Intuition }\end{array}$ & $\begin{array}{c}\text { Collective } \\
\text { Archetype Intuition }\end{array}$ & $\begin{array}{c}\text { Collective } \\
\text { Universal Intuition }\end{array}$ \\
\hline $\begin{array}{c}\text { Emptiness } \\
\text { Pure brightness } \\
\text { Personal Experience } \\
\text { Intuition }\end{array}$ & $\begin{array}{c}\mathbf{5 7 1}(* *) \\
\begin{array}{c}\text { Collective Archetype } \\
\text { Intuition }\end{array}\end{array}$ & $.196(*)$ &. $\mathbf{1 8 1}(*)$ & 1 & \\
$\begin{array}{c}\text { Collective Universal } \\
\text { Intuition }\end{array}$ & $.529(* *)$ & $\mathbf{. 4 7 6}(* *)$ & $.310(* *)$ & $.341(* *)$ & 1 \\
\hline $\mathrm{p}$ values: $*<0.05 ; * *<0.01, * * *<0.001$ & & & & \\
\end{tabular}

\subsection{Regression}

\section{- H1 testing:}

To validate further the results, a regression analysis using emptiness was conducted for pure brightness. The $\mathrm{F}$ score was significant $\left(74.944, \mathrm{p}\right.$-value $=0.000,<0.05$ ), $\mathrm{R}^{2}$ was 0.326 , and the adjusted $\mathrm{R}^{2}$ was 0.322 (Table 3 ). Therefore, H1 was supported.

Table 3. Regression Model and Results for H1

\begin{tabular}{cc}
\hline Emptiness (independent variable) & Pure brightness (dependent variable) \\
\hline Standard coefficient (Beta) & 0.571 \\
$\mathrm{R}^{2}$ & 0.326 \\
Adjusted $\mathrm{R}^{2}$ & 0.322 \\
$\mathrm{~F}$ value & 74.944 \\
p-value & $0.000^{*}$ \\
\hline
\end{tabular}

$*<0.001$

\section{- H2, H3, and $\mathrm{H} 4$ testing:}

Statistical significance was observed for the correlation of pure brightness with personal experience intuition (PEI), collective archetype intuition (CAI) and collective universal intuition (CUI). The independent variable here is pure brightness, and the dependent variables are PEI, CAI, and CUI. The $F$ scores for the models had statistical significance $\left(\mathrm{PEI}=5.279, \mathrm{p}=0.023 * ; \mathrm{CAI}=20.993, \mathrm{p}=0.000^{* * *} ; \mathrm{CUI}=45.479, \mathrm{p}=0.000 * * *\right)$, and all beta values for the measurements of moral recognition, moral judgment, and moral intention were statistically significant $(0.181,0.345,0.476)$. Thus, $\mathrm{H} 2, \mathrm{H} 3$, and $\mathrm{H} 4$ were supported.

\subsection{Testing the Proposed Model}

The proposed model was examined further using SEM techniques with the software AMOS. The results of SEM for PEI indicated a good fit of the model $\left(\chi^{2}=166.140, \mathrm{df}=88, \chi 2 / \mathrm{df}=1.888, \mathrm{GFI}=0.882\right.$, AGFI $=0.839$, $\mathrm{PNFI}=0.785, \mathrm{CFI}=0.883, \mathrm{RMR}=0.075, \mathrm{RMSEA}=0.075) . \chi^{2} / \mathrm{df}(2.025)$ was lower than 3 . Additionally, GFI (0882), AGFI (0.839), and PNFI (0.624) were over $0.8,0.8$, and 0.5 , respectively, falling within the suggested index (Schumacker and Lomax, 2010). The CFI (Bentler, 1989), at0.883, indicated a good fit. Overall, the proposed model performed well (Figure 1). 


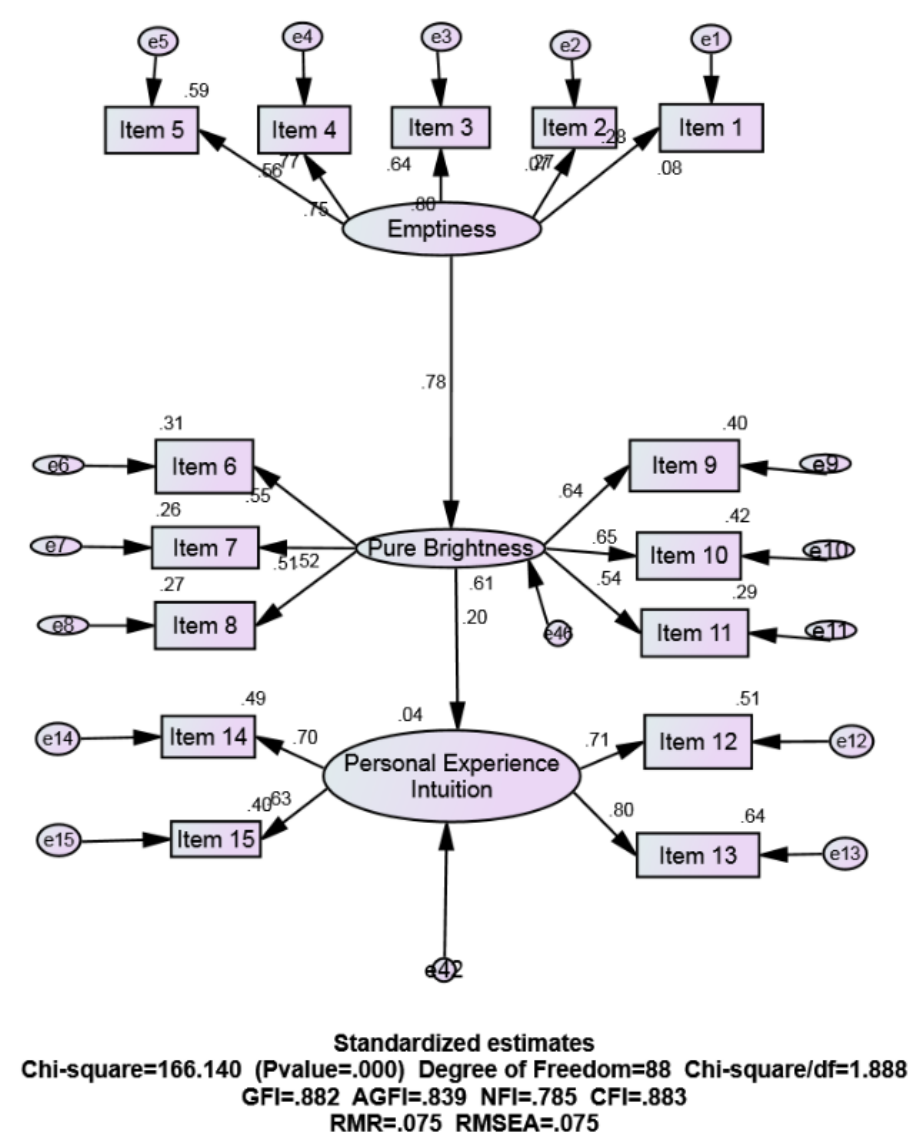

Figure 1. The SEM Model of Emptiness to Personal Experience Intuition

\subsection{Testing the Rival Model}

Table 4. Rival Models

\begin{tabular}{|l|l|l|l|}
\hline & Proposed model: Hypothesis1 & Rival model 1: Hypothesis 2 & Rival model 2: Hypothesis 3 \\
\hline & &
\end{tabular}

EM: emptiness; PB: pure brightness; PEI: personal experience intuition; CAI: collective archetype intuition; CUI: collective universal intuition; CR: critical ratio (i.e., t-value). 
An emerging consensus in SEM is that researchers should compare rival models, not just test a proposed model (Bollen \& Long, 1992). Our extremely parsimonious model posits that pure brightness will be positively associated with PEI; this implies a nomological status for CAI and CUI. This study compared (Table 4) the proposed model with two rival models on the following criteria: (1) overall fit of the model-implied covariance matrix to the sample covariance matrix, as measured by CFI, (2) the models' hypothesized parameters that are statistically significant, and (3) parsimony, as measured by the PNFl (James, Mulaik, \& Brett, 1982). Because the model fit indexes of the three models were nearly the same, the proposed model and two rival models performed well.

For the estimate of the path from emptiness to pure brightness in three models, the critical ratios (t-value) were $5.395,5.347$, and 5.433, respectively. All had statistical significance because their $\mathbf{p}$ is smaller than $\mathbf{0 . 0 0 1}$. Thus, H1 was supported.

Regarding the path from pure brightness to each intuition, all path estimates were significant $(\mathrm{CR}=1.997 ; 3.561$; 4.627). This finding implies that pure brightness is significantly positively associated with PEI, CAI, and CUI. Thus, $\mathrm{H} 2, \mathrm{H} 3$, and $\mathrm{H} 4$ were supported.

\section{Discussion and Implications}

\subsection{Outline of the results}

This study investigated the association between emptiness and intuitive judgment. With the use of correlation, regression, and SEM analysis, a statistically significant correlation was found between emptiness and pure brightness using a questionnaire-based survey with 157 spirit mediums. Pure brightness also had a significantly positive association with three types of intuition (PEI, CAI, and CUI). This finding indicates that emptiness has a critical role in explaining attitudes toward intuitive judgment. Thus, $\mathrm{H} 1, \mathrm{H} 2, \mathrm{H} 3$, and $\mathrm{H} 4$ were supported.

\subsection{Limitations of the study}

An investigation into the relationship between emptiness and intuition is a difficult endeavor and will be constrained by numerous limitations. Varying definitions of intuition constrain comparability of this study to similar studies. Additionally, research on the dynamic associations between emptiness and intuition can be approached using various research questions, designs, and hypotheses. The results of this study, therefore, require careful interpretation to avoid conclusions that overreach the data. Furthermore, the fact that many respondents in this research were Taiwanese must be considered when interpreting the results. Including variables of different cultural and religious backgrounds in future research may improve the understanding of the nuances of intuitional influences on ethical decision-making processes.

\subsection{Practical Implications}

As Narvaez (2010) notes, because we think in and through our bodies, our thinking is bounded and shaped by them, making our conceptual systems unconscious, metaphorical, and imaginative. Consistent with this notion, reason and intuition should intricately interweave in moral psychology and neuroscience. Moral evaluation is, therefore, not only a process of reason but also guided by metaphors of purity (Zhong \& Liljenquist, 2006), influenced by affect and emotions (Haidt, 2001). However, the influence of these dynamics on intuition is largely unconscious and are not best captured by current calculative and analytic tools (Zhong, 2011).

The school of Vijñānavāda claims that the experience of knowledge is determined solely by the individual predispositions of the knowing subject (his "imprints of the linguistic constructions-Abhilapavasana) and not by an alleged "external reality (Nedu, 2015, p52).Thus, Vijñānavāda texts consider that fact is affected by the illusions of the determined individuality and of subjectivity, which obstruct the absolute and liberated condition of reality. The mana, in its essence, is responsible for the illusory appearance of the ego of the individual. Through the determining relation it exerts on the mental consciousness, the manas also transfers obstructed nature to mental consciousness (Nedu, 2015).

According to the concept of Mādhyamaka, Tathagatagarbha is inherently pure, and everyone has Buddha nature. However, how can this intrinsically pure nature be contaminated by extrinsic and other virulent defilements? As the Sutra of Queen Srimala of the Lion's Roar (勝蔓經) notes, there are defilements (such as fundamental and derivative afflictions), and there are defiled consciousnesses (such as mental consciousness and manas consciousness). In other words, both the mental and the manas consciousness should be inherently pure but have been innately contaminated by fundamental afflictions such as greed, anger, doubt, and improper views. This situation is called ignorance (avijja) from or before the very beginning. Therefore, the manas is not moral intuition and cannot make appropriate ethical decisions if afflictions defile it. Mental consciousness will then follow its decision to act unethically. In other words, only moral intuition can result in a moral judgment and 
thereby moral action. The non-moral effect is caused just by non-moral judgment, which arises from non-moral intuition. This concept is in line with moral psychology, in its assertion that moral intuitions come first and directly cause moral judgments (Shweder \& Haidt, 1993).

Accordingly, the gap between judgment action is similar to that in Kant's morality, which is universal and necessary (a priori). This gap between judgment and action also exists a priori. The gap that occurs does not involve an incongruity between moral judgment and non-moral action. Instead, the gap directly displays that moral judgment is not genuinely moral and is thus able to result in non-moral action. This gap will not occur if the moral judgment is genuinely moral. Therefore, this paper argues that the gap between judgment and action is just an extended comparison between non-moral judgment and non-moral action.

\section{Conclusion}

The study reported here provides evidence that emptiness has a positive effect on intuition, no matter what intuition it is. It implies that emptiness (Mādhyamaka) can improve the decision-making process of the eight consciousnesses (Vijñānavāda). Much work has been done already to examine the link between intuitive cognition and moral judgment. However, much work is also required to understand the relationship between moral judgments and antecedent factors, such as karma or afflictions.

Although Mādhyamaka and Vijñānavāda are distinct from each other in their doctrines, this empirical study suggests their approaches are closely associated with intuitive moral judgments. This paper is not able to address all the potential vital deficiencies in the current state of moral judgment theory. However, if a new proposed theoretical model can at least adequately take into account the primary concerns of consciousness raised by Vijñānavāda, a potentially more robust model will have been developed for use by a broader range of empirical researchers.

\section{Acknowledgments}

We mainly thanks, Taiwan Mediums' Association for this research support.

\section{References}

Allinson, C. W., \& Hayes, J. (1996). The cognitive style index: A measure of intuition-analysis for organizational research. Journal of Management Studies, 33, 119-135. doi:10.1111/j.1467-6486.1996.tb00801.x.

Ayoun, B., Rowe, L., \& Yassine, F. (2015). Is workplace spirituality associated with business ethics? International Journal of Contemporary Hospitality Management, 27, 938-957. https://doi.org/10.1108/IJCHM-01-2014-0018.

Badiane, K. (2015). Intuitive judgment: A vigilant market learning capacity [Doctoral Dissertation]. Feng Chia University, Taiwan.

Bentler, P. M. (1989). EQS structural equations program manual. Los Angeles, CA: BMDP.

Berzin, A. (2013). English glossary of Buddhist terms. (https://studybuddhism.com/web/en/index.html)

Blasi, A. (1995). Moral understanding and the moral personality: The process of moral integration. In W. M. Kurtines, \& J. L. Gewirtz (Eds.), Moral development: An introduction (pp. 229-253). Boston: Allyn and Bacon.

Bollen, K. A., \& Long, J. S. (1992).Tests for structural equation models. Sociological Methods and Research, 21, 123-131. https://doi.org/10.1177/0049124192021002001.

Buswell, R. E. (1989). The Formation of Ch'an Ideology in China and Korea: The Vajrasamadhi-Sutra, a Buddhist Apocryphon. Princeton, NJ: Princeton University Press.

Buswell, R. E., \& Lopez, D. S. (2013). The Princeton Dictionary of Buddhism. Princeton, NJ: Princeton University Press.

Campbell, D.T., \& Stanley, J.C. (1963). Experimental and quasi-experimental designs for research. Dallas, TX: Houghton-Mifflin.

Chan, M. G. (2015). Activate your self-nature DNA. Taipei: The Corporate Body of the Buddha Education Foundation. The Corporate Body of the Buddha Education Foundation.

Cheng Kuan. (2015). The Heart Sutra. Taipei: The Corporate Body of the Buddha Education Foundation.

Chin Kung. (2015). The awakening of compassion and wisdom. Taipei: The Corporation Republic of Hwan Dzan. 
Clark, J. (2008). The eighth consciousness of the Yogacara. Middle Way, 83, 67-77.

Clark, J. (2011). The seeds of awakening. Middle Way, 86, 147-161.

Clart, P. (2003). Moral Mediums: Spirit-Writing and the Cultural Construction of Chinese Spirit-Mediumship. Negotiating Transcendence, 25(1), 153-189. https://10.7202/007129ar.

Cline, E. M. (2010).Female Spirit Mediums and Religious Authority in Contemporary Southeastern China. Modern China, 36(5), 520-555. https://doi.org/10.1177/0097700410372921

Duckworth, D. (2014). Onto-theology and emptiness: The nature of Buddha-nature. Journal of the American Academy of Religion, 82, 1070-1090. https://doi.org/10.1093/jaarel/lfu063.

Eskildsen, S. (2015).Daoism, Meditation, and the Wonders of Serenity. From the Latter Han Dynasty (25-220) to the Tang Dynasty (618-907). New York: State of the University of New York.

Fontein, J. (2006). Shared legacies of the war: spirit mediums and war veterans in Southern Zimbabwe. Journal of Religion in Africa, 36(2),167-199. https//10.1163/157006606777070687

Giacalone, R. A., \& Jurkiewicz, C. L. (2003). Right from wrong: The influence of spirituality on perceptions of unethical business activities. Journal of Business Ethics, 46, 85-97. https://doi.org/10.1023/A:1024767511458.

Goleman, D., Kaufman, P., \& Ray, P. (1992). The creative spirit. New York: Penguin Putnam.

Haidt, J. (2001). The emotional dog and its rational tail: A social intuitionist approach to moral judgment. Psychological Review, 108, 814-834. https://doi.org/10.1037/0033-295X.108.4.814.

Hair, J. F. Jr., Anderson, R. E., Tatham, R. L., \&Black, W. C. (1992). Multivariate data analysis with reading (3rd ed.). New York: Macmillan Publishing Company.

Hancock, G. (2015). Fortune Cookies, Measurement Error, and Experimental Design. Journal of Modern Applied Statistical Methods, 2 (2), 293-305. https//10.1016/j.pmcj.2014.09.002

James, L. R., Mulaik, S. A., \& Brett, J. (1982).Causal analysis: Models, assumptions, and data. Newbury Park, CA: Sage Publications.

Jung, C. G. (1981). Archetypes and the collective unconscious. Collected works (Vol. 9). (R.F.C. Hull, Trans.). Princeton, NJ: Princeton University Press.

Jung, C. G. (1989). Memories, dreams, reflections. London: Fontana Press.

Kaag, J. J. (2012). Emptiness, selflessness, and transcendence: William James's reading of Chinese Buddhism. Journal of Chinese Philosophy, 39, 240-259. https://doi.org/10.1111/j.1540-6253.2012.01716.x.

King, R. (1994). Early Yogācāra and its relationship with the Madhyamika school. Philosophy East and West, 44, 659-683. https://doi.org/10.2307/1399757.

Lee, S. (2016). From criticism to approval: A reconsideration of Ji'sYogācāra position on Madhyamaka. Asian Philosophy, 26, 329-353. https://doi.org/10.1080/09552367.2016.1239309.

Loehlin, J.C. (2004). Latent variable models: An introduction to factor, path and structural analysis. Hillsdale, NJ: Lawrence Erlbaum.

Marshall, A.R. (2003). Moving the Spirit to Taiwan: New Age Lingi Performance. Journal of Chinese Religions, 31 (1), 81-99. https//dx.doi.org/10.1179/073776903804760120

Marshall, A. (2004). Taiwanese shamanic performance and dance." pp. 736-39 in Mariko Namba Walter and Evan Jane Neumann Fridman (eds.), Shamanism: An Encyclopedia of World Beliefs, Practices, and Culture. Santa Barbara, CA: ABC-CLIO.

McCoach D.B., Black, A.C. \& o; CONNELL, A.A. (2007), Errors of Inference in Structural Equation Modeling. Psychology in the Schools, 44(5), 461-470. https://10.1002/pits.20238

Narvaez, D. (2010). Moral complexity: The fatal attraction of truthiness and the importance of mature moral $\begin{array}{lllll}\text { functioning. Perspectives on } & \text { Psychological }\end{array}$ https://doi.org/10.1177/1745691610362351.

Nickerson, P. (2001). A poetics and politics of possession: Taiwanese spirit-medium cults and autonomous popular cultural space. Positions, 9 (1), 187-217. https//doi.org/10.1215/10679847-9-1-87.

Nedu, O. (2015). A non-referential and non-cognitive theory of truth in Vijñānavāda Buddhism. Hyperborea, 2 , 
$52-73$.

Nunnally, J. C. (1994). Psychometric theory (3rd ed.). New York: McGraw Hill.

Paper, J. (1995). The Spirits are Drunk: Comparative Approaches to Chinese Religion. Albany: SUNY Press.

Paper, J. (1996). Mediums and modernity: the institutionalization of ecstatic religious functionaries in Taiwan. Journal of Chinese Religions, 24, 105-30. https//dx.doi.org/10.1179/073776996805307120

Pilard, N. (2015). Jung and intuition: On the centrality and variety of forms of intuition in Jung and post-Jungians. London: Karban Books Ltd.

Pine, R. (2013).The Lankavatara Sutra: Translation and commentary. Berkeley, CA: Counterpoint.

Raff, J. (2000). Jung and the alchemical imagination (Jung on the Hudson book series). Newburyport, MA: Hays (Nicolas) Ltd.

Raines-Eudy, R. (2000). Using structural equation modeling to test for differential reliability and validity : An empirical demonstration. Structural Equation Modeling, 7, 124-141. https://doi.org/10.1207/S15328007SEM0701_07.

Schumacker, R. E., \& Lomax, R. G. (2010).A beginner's guide to structural equation modeling (2nd ed.). Mahwah, NJ: Lawrence Erlbaum Associates.

Shamdasani, S. (Translator). (2009). Jung. C. G. Liber Novus (the new book). Publisher. New York: W. W. Norton \& Company.

Shultz, D., \& Shultz, S. (2009). Theories of personality (9th ed.). Belmont, CA: Wadsworth Publishing, Cengage Learning.

Shweder, R. A., \& Haidt, J. (1993). The future of moral psychology: Truth, intuition, and the pluralist way. Psychological Science, 4, 360-365. https://doi.org/10.1111/j.1467-9280.1993.tb00582.x.

Siderits, M. (2005). The Buddhist Unconscious: The Alayavijñāna in the context of Indian Buddhist thought (review). Philosophy East and West, 55, 358-363. https://doi.org/10.1353/pew.2005.0012.

Sutton, D. (1989). Ritual trance and the social order: the persistence of Taiwanese shamanism. Pp. 108-27 by Andrew E. Barnes and Peter N. Stearns (eds.), Social History and Issues in Consciousness: Some Interdisciplinary Connections. New York: New York Univ. Press.

Sutton, D. (1990). Rituals of self-mortification: Taiwanese spirit mediums in comparative perspective. Journal of Ritual Studies, 4 (1): 99-125.

Sutton, D. (2003). Steps of Perfection: Exorcistic Performers and Chinese Religion in Twentieth-Century Taiwan. Cambridge, MA: Harvard University Asia Center and Harvard Univ. Press.

Tripitaka Master Xuanzang, (AD 596-664),'Verses delineating the eight consciousnesses' (Ronald. Epstein, trans in 1986), A Monthly Journal of Orthodox Buddhism, 336, May (1998).

Venerable, C. K. (2005).The diamond sutra and the heart sutra. Taipei: The Corporate Body of the Buddha Educational Foundation.

Waldron, W. S. (2006). On selves and selfless discourse. In M. Unno (Eds.), Buddhism and Psychotherapy Across Cultures: Essays on Theories and Practices. (pp.105-128). Boston: Wisdom Pub.

Waldron, W. (2008). A Buddhist theory of Unconscious Mind [ālayavijñāna]. In K. R. Rao, A. Paranjpe, \& A. K. Dalal (Eds.), Handbook of Indian psychology. Cambridge: Foundation Books.

Zhong, C. B. (2011). The ethical dangers of deliberative decision making. Administrative Science Quarterly, 56, 1-25. https://doi.org/10.2189/asqu.2011.56.1.001.

Zhong, C. B., \& Liljenquist, K. (2006). Washing away your sins: Threatened morality and physical cleansing. Science, 313, 1451-1452. https://doi.org/10.1126/science.1130726.

Buddhist Dharma:

The Heart Sutra (心經)

Verses Delineating the eight consciousnesses (八識規矩頌)

Sutra of Queen Srimala of the Lion's Roar (勝蔓獅子吼大方辯方廣經) 


\section{Appendix}

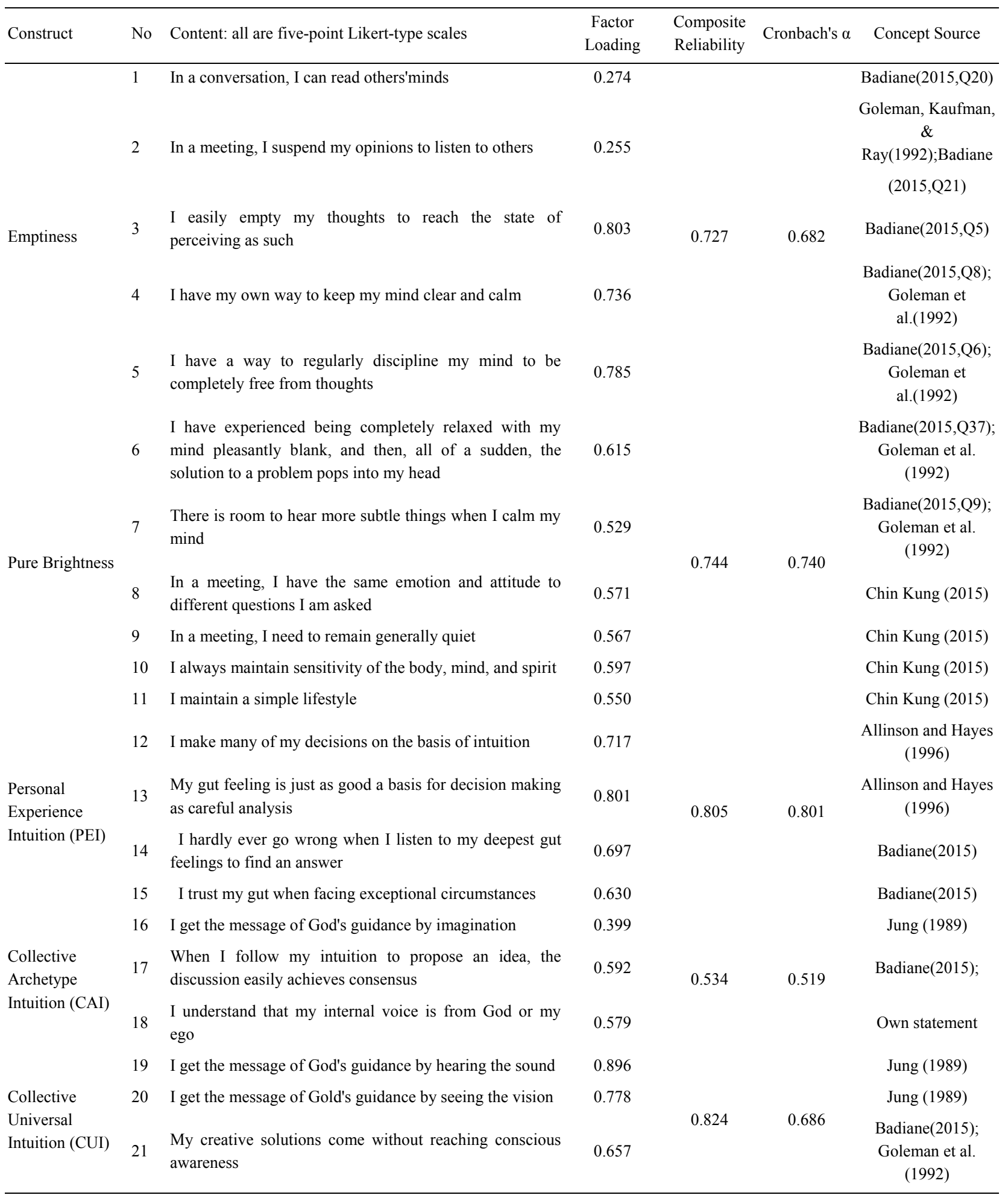

\section{Copyrights}

Copyright for this article is retained by the author(s), with first publication rights granted to the journal.

This is an open-access article distributed under the terms and conditions of the Creative Commons Attribution

license (http://creativecommons.org/licenses/by/4.0/). 